\title{
Behavioural Intention Determinants of Augmented Reality Technology Adoption in Supermarkets/Hypermarkets
}

\author{
Ivan Jajić, Faculty of Economics and Business, University of Zagreb, Croatia \\ Mario Spremić, Faculty of Economics and Business, University of Zagreb, Croatia \\ (iD) https://orcid.org/0000-0001-8114-0213 \\ Ivan Miloloža, Faculty of Dental Medicine and Health, University of Osijek, Croatia
}

\begin{abstract}
In this paper, the adoption of augmented reality, as one of the emerging and intriguing digital technologies, has been investigated. This research uses the extended unified theory on acceptance and use of technology framework to analyze these factors. The student population respondents' data about augmented reality adoption was collected. The student population has been chosen due to the highest probability of accepting new technologies. The research results show a positive and significant performance expectancy and enjoyment, while effort expectancy showed a negative and significant impact on the behavioral intention dependent variable. These research results can be used for the potential development of augmented reality apps in the retail industry and the academic implications of the connections between variables in the UTAUT framework.
\end{abstract}

\section{KEYWORDS}

Adoption, Augmented Reality, Hypermarkets, Intention, Mobile Commerce, Retail, Structural Equation Modelling, Supermarkets, UTAUT

\section{INTRODUCTION}

A high level of application of ICT and digital technologies enables numerous multiplicative benefits and innovative business models. The impact of a technological breakthrough on the transformation of economic structure, labour market and individual businesses has attracted researchers for decades.

Digital Transformation relates to the fourth technological revolution that impacts the companies' way of doing business to stay competitive. Both internal and external factors are needed to provide and implement digital operations (Tomcic Furjan et al., 2020). The Digital Economy (DE) refers to a recent shift in a series of technological breakthroughs that transformed economic structures and altered the productivity of world economies since the dawn of the first industrial revolution. The term $\mathrm{DE}$ is used in everyday communication and is also referred to as Industry 4.0 or the fourth industrial revolution, complementing almost all industries' galloping digital transformation (Pejić et al., 2018).

Developments in new digital technologies are an essential step towards a more efficient lifestyle. Still, mass adoption depends on the two aspects, originality/value and price, if all other factors are constant (Plewa et al., 2012). Although Augmented Reality technology has been researched for a long time (from the 1980s), it has only been implemented in the general population in the last decade

DOI: 10.4018/IJESMA.289632

This article published as an Open Access article distributed under the terms of the Creative Commons Attribution License (http://creativecommons.org/licenses/by/4.0/) which permits unrestricted use, distribution, and production in any medium, provided the author of the original work and original publication source are properly credited. 
(Ghazali et al., 2019). This step has been enabled due to increased mobile technology development, especially smartphones, network improvements and general high usage percentage due to mass production and affordability throughout the world. The prerequisites for adopting and efficient usage of Augmented Reality have made it possible in recent years. The Augmented Reality technology requires a user to have a standard smartphone with an integrated camera and good internet connectivity. These steps are essential as AR apps operate to implement virtual objects in a user's environment (Saprikis et al., 2020).

This paper analyzed the potential understanding and willingness to use Augmented Reality apps among the student population in supermarkets and hypermarkets. The student population has been taken as they represent the most technology-oriented part of the overall population. In the retail industry, super and hypermarkets are widely visited, and their shopping process is well known. Therefore, any innovation implemented in the already known environment will have an immediate response from its customers.

The main goal of this paper is to investigate whether Augmented Reality apps are widely accepted as innovations in retail. In this regard, certain aspects will be taken into consideration, namely the following research questions: (i) RQ1: What factors and behavioural parameters have motivated the respondents' opinion on AR apps in super and hypermarkets?; (ii) RQ2: What factors stimulate individuals the most to adopt AR apps? These questions will be answered using the extended Unified Theory on Acceptance and Use of Technology (UTAUT) research framework.

The structure of this paper is as follows: after introduction, the research framework and literature review is provided in the second part, followed by the explanation of the methodology used, third part, more detailed approach on relevant factors affecting the adoption of Augmented Reality technology will be described in the fourth part. On top of the above, the research is to understand and discuss how and in what ways companies could implement AR apps easier in the retail sector based on this research results in the fifth part of the paper.

\section{LITERATURE REVIEW AND RESEARCH FRAMEWORK}

\section{Augmented Reality}

The digital economy relies heavily on several independently developed but simultaneously used digital technologies that have transformed almost all industries and business models (Spremić, 2017). Digital technologies combine information technology, computer science, communication and connectivity technologies (Bharadway, 2013).

According to the current stage of development, we can distinguish between basic (primary) and advanced (emerging, secondary) digital technologies (Weill et al., 2004, Mydyti et al., 2021). Essential digital technologies most often include mobile and communication technologies, social networks, cloud computing, advanced data analytics, sensors and the Internet of Things (IoT). We consider them essential because their application is inevitable in almost all industries. For example, almost all companies use cloud computing services to store content or rent and pay for IT services to the extent that they are used, which reduces the need for capital investment and allows business development. The application of unique digital technologies provides visible and tangible benefits for businesses. Still, the combined, simultaneous application of many independently developed digital technologies enables disruptive innovations and innovation of the entire business model. Digital technologies can extract information from physical devices (data on sensors and IoT devices), disseminate it (using mobile technologies like 5G), store it on the cloud, analyze it instantly (using big data and advanced data analytics) and thereby connecting products, services, business processes and enabling entirely new business models (Spremić, 2017).

Emerging digital technologies may not yet have reached their full potential and usually include the following technologies: artificial intelligence (AI), virtual and augmented reality (VR and AR), 
robotics (RPA, robot process automation), 3D printers, blockchain, drones, etc. The application of unique digital technologies provides visible and tangible benefits for businesses (Merkaš et al., 2020). Still, the combined, simultaneous application of many independently developed digital technologies enables disruptive innovations and innovation of the entire business model (Spremić et al., 2020).

Augmented reality (AR) describes the virtual world connected with the physical one in realtime. The Augmented Reality is the gateway to the virtual world for those interested in stepping away from reality. It is often described as changing our opinion of individuals seeing the physical world (Pine et al., 2011). Economies of scale helped us reduce smartphone and gadget production costs in general, making it more affordable to more significant masses. The Augmented Reality technology could be developed and distributed adequately among the population, as smartphones became widely used (Olsson et al., 2011). The ordinary smartphone is equipped with standard hardware, a 4G/5G high-speed network, a built-in camera and a relatively large screen (Saprikis et al., 2020). These prerequisites are needed for implementing, installing and using Augmented Reality apps. One of the first industries to implement Augmented Reality technology was the gaming industry (van Boom, 2019). Gaming was always at the front of technological advances as psychologically emotions are the ones that drive our decisions sometimes. Therefore, implementing a mobile gaming app, "Pokemon Go", brought not only emotions into "the game" but nostalgia as well (Wulf et al., 2020). The game offered something completely different from those offered games, such as using your phone and camera to play the game outdoors or indoors. Being in a virtual world through your camera's lens while walking on the ground was new to the audience. When you combine it with nostalgia from the "Pokemon" series, the Augmented Reality technology got spread pretty fast (Ghazali et al., 2019). Not shortly afterwards, the Augmented Reality technology got included in various industries from tourism, retail, education, marketing, etc. (Chung et al., 2015, Kourouthanassis et al., 2015), which concluded that its momentum has begun. One of the industries that could witness a big Augmented Reality and virtual reality (VR) influence is the retail industry, on which projections estimate a USD 1.6 billion worth of investments by 2025 will be made (Goldman Sachs, 2016).

The benefits of using AR technology are significant in the COVID-19 pandemic time as it allows users to test certain products at home. Those products could be Sephora's makeup line or IKEA's furniture, which would otherwise be only possible to check in the store (Kim et al., 2008, Huang et al., 2015). These examples are part of the retail sector, which needs digital transformation and technological advances. Customers can stay at their homes while using smartphones and check out any makeup colour they like or see if the wishing table fits their living room, for example (Rese et al., 2014). It is an addition to the classic e-commerce websites, and a complement as those websites will be more interesting for the consumer. The decision-making process speeds up, but ques in stores shorten, while costs for the companies decrease (Lee 2012). By using the Augmented Reality apps, companies have the advantage over their customers in dictating any discounts, offers or "hidden gems" that could only be opened while using the app as the number of users for a specific Augmented Reality app increases, the better for the company that implemented it as its P\&L will undoubtedly be better (Rese et al., 2014). Lack of information such as lousy product photos or inadequate information cannot happen with the Augmented Reality app. They provide customers with an experience that looks like the real world. (Verhagen et al., 2014).

Furthermore, the Augmented Reality apps' usage is extensive and is entirely defined by the environment in which they are functioning. An Augmented Reality app in online shopping is not the same as the one in the store, although they all use the same platform technology (Alkhamisi et al., 2013). A user in the store might scan a product and receive all the necessary ingredients information, discount offers, expiry date or any other related info. On the other hand, the same is possible in the online version of the Augmented Reality app only in a bit different context as the reality is you or your environment. In contrast, in the store, the environment is the products. Knowing the environment, its usage potential, and the targeted audience, the Augmented Reality apps might differ slightly from 
Table 1. Various industries new technology adoption including augmented reality

\begin{tabular}{|c|c|c|}
\hline Authors & Paper title & Key findings \\
\hline $\begin{array}{l}\text { Martincevic et al. } \\
(2020)\end{array}$ & $\begin{array}{l}\text { Fintech Revolution in the } \\
\text { Financial Industry }\end{array}$ & $\begin{array}{l}\text { The research results confirm that the usage of new } \\
\text { technologies, such as "Neobanks" (banks without a physical } \\
\text { location), are evolving and are incorporated into companies to } \\
\text { increase their added value and gain a competitive advantage } \\
\text { on the market. }\end{array}$ \\
\hline Simicevic et al. (2020) & $\begin{array}{l}\text { The utilization of } \\
\text { Forecasting Methods for } \\
\text { Cryptocurrencies }\end{array}$ & $\begin{array}{l}\text { According to various forecasting methods used (market } \\
\text { capitalization. moving average), the findings show that } \\
\text { Bitcoin will continuously grow until } 2023 \text {. }\end{array}$ \\
\hline Topalovic et al. (2020) & $\begin{array}{l}\text { Data Mining Applications in } \\
\text { SMEs: An Italian Perspective }\end{array}$ & $\begin{array}{l}\text { They conclude that data mining techniques can boost a } \\
\text { company's operations but indicate that only large companies } \\
\text { implement it in Italy. }\end{array}$ \\
\hline Tsioustas et al. (2020) & $\begin{array}{l}\text { Innovative Applications of } \\
\text { Natural Language Processing } \\
\text { and Digital Media in Theatre } \\
\text { and Performing Arts. }\end{array}$ & $\begin{array}{l}\text { They investigated new digital techniques and tools, offering } \\
\text { innovative, attractive, enhanced, and accessible theatre } \\
\text { experiences. The goal was to remove accessibility, language } \\
\text { and geography barriers and to be able to achieve the opening } \\
\text { of theatrical performances to important additional audience } \\
\text { groups. }\end{array}$ \\
\hline Mabic et al. (2019) & $\begin{array}{l}\text { Do Higher Education } \\
\text { Institutions Foster Critical } \\
\text { Thinking? - Students' } \\
\text { Perspective }\end{array}$ & $\begin{array}{l}\text { The results of their research show that students think } \\
\text { that teachers have to encourage them to critical thinking. } \\
\text { According to students, critical thinking primarily means } \\
\text { looking at the issue from different perspectives. Students are } \\
\text { aware of the importance of developing their critical thinking } \\
\text { to be better prepared for their future jobs. }\end{array}$ \\
\hline Liu et al. (2019) & $\begin{array}{l}\text { Comparison of Augmented } \\
\text { Reality and physical. } \\
\text { the experiential learning } \\
\text { environment in supporting } \\
\text { product innovation }\end{array}$ & $\begin{array}{l}\text { The research results show no significant differences in virtual } \\
\text { and physical learning environments concerning product } \\
\text { innovation. On the other hand, the selection of mechanisms } \\
\text { for ideation showed differences. }\end{array}$ \\
\hline Opila et al. (2019) & $\begin{array}{l}\text { Role of visualization in a } \\
\text { knowledge transfer process }\end{array}$ & $\begin{array}{l}\text { The research findings suggest that special care must be } \\
\text { devoted to visualization, especially clarity, optimal details and } \\
\text { information density to avoid obfuscation. }\end{array}$ \\
\hline Kounavis et al., 2012 & $\begin{array}{l}\text { Enhancing the tourism } \\
\text { experience through } \\
\text { mobile augmented reality: } \\
\text { Challenges and prospects }\end{array}$ & $\begin{array}{l}\text { Acknowledging the various technological limitations } \\
\text { hindering AR's substantial end-user adoption, the paper } \\
\text { proposes a model for developing Augmented Reality mobile } \\
\text { applications for tourism, aiming to release Augmented } \\
\text { Reality's full potential within the field. }\end{array}$ \\
\hline
\end{tabular}

Source: Author's work

each other but are very similar in the end. Given the general usage of new technologies and AR, Table 1 provides an overview of such articles across various industries.

When we incorporate Augmented Reality technology into this research, we can start with the Technology acceptance framework (TAM) and continue towards the Unified Theory of Acceptance and Use of Technology (UTAUT) model. The model was developed by Venkatesh et al. (2003), representing the factors that influence users' acceptance of new technologies, such as Augmented Reality.

\section{Technology Acceptance Framework}

Although new digital industrial technologies are already there, the overall benefits of this advancement are likely to become visible over the medium to long term horizon of the next 15 to 20 years. The period until then, however, is likely to witness structural transformation within all industries. Another 
set of theoretical explanations is offered through lenses of technology acceptance model (TAM) and technology enactment literature (Zhao et al., 2015, Ali et al., 2018). TAM literature is generally concerned with channels through which new technologies lead to changes in the behaviour of economic agents such as organizations or firms.

Since Unified Theory on Acceptance and Use of Technology introduction, it has been used in various fields due to its expanded model regarding TAM. It incorporates a comprehensive examination of four independent vital factors: performance expectancy, effort expectancy, social influence and facilitating conditions. The first three variables are directly related to usage intention and behaviour during the last one of user behaviour. There are four moderate variables such as gender, age, experience and voluntariness. Still, this research used a fixed sample of student respondents and thus will only use gender and education as control variables. As the research interest is in the usage intention, it will disregard facilitating conditions as a factor for user behaviour. It is only concentrated on the consumer intention to use the Augmented Reality app. Therefore, this model is a good representation in explaining user perception and acceptance behaviour regarding new technological advances. Several prior related studies were examined to expand the original Unified Theory on Acceptance and Use of Technology model in the Augmented Reality scope. Table 2 presents a summary of related researches on this topic.

Table 2. Literature review of recent research of AR adoption

\begin{tabular}{|l|l|l|}
\hline \multicolumn{1}{|c|}{ Authors } & \multicolumn{1}{|c|}{ Paper title } & \multicolumn{1}{c|}{ Key findings } \\
\hline Shang et al. (2017) & $\begin{array}{l}\text { Mobile augmented reality } \\
\text { applications for heritage } \\
\text { preservation in UNESCO } \\
\text { world heritage sites through } \\
\text { adopting the UTAUT model }\end{array}$ & $\begin{array}{l}\text { The effect of performance expectations and facilitating } \\
\text { conditions on adopting a mobile AR app for historical } \\
\text { monuments are found to be significant. }\end{array}$ \\
\hline Paulo et al. (2018) & $\begin{array}{l}\text { Understanding mobile } \\
\text { augmented reality adoption in } \\
\text { a consumer context }\end{array}$ & $\begin{array}{l}\text { The UTAUT was used to investigate the use of augmented } \\
\text { reality in tourism. The authors demonstrated that enabling } \\
\text { environments and performance expectations affected the } \\
\text { variable of behavioural adoption intention. }\end{array}$ \\
\hline Ghazali et al. (2019) & $\begin{array}{l}\text { Exploring player behaviour } \\
\text { and motivations to continue } \\
\text { playing Pokémon GO }\end{array}$ & $\begin{array}{l}\text { The findings revealed that enjoyment, network externalities, } \\
\text { community involvement, and the drive to gather substantially } \\
\text { impact users' inclination to keep playing. Furthermore, the } \\
\text { data show that flow and nostalgia indirectly impact players' } \\
\text { intention to keep playing, significantly impacting their buy } \\
\text { intention. }\end{array}$ \\
\hline Saprikis et al. (2020) & $\begin{array}{l}\text { Determinants of the Intention } \\
\text { to Adopt Mobile Augmented } \\
\text { Reality Apps in Shopping } \\
\text { Malls among University } \\
\text { Students }\end{array}$ & $\begin{array}{l}\text { The findings demonstrate that performance expectations, } \\
\text { enjoyment, and reward are direct determinants of adopting } \\
\text { a specific technology in shopping malls, whereas enabling } \\
\text { conditions, social influence, innovativeness, and trust } \\
\text { indirectly affect behavioural intention adoption. }\end{array}$ \\
\hline
\end{tabular}

Source: Author's work

The research framework has been based on the literature review that includes the following factors: performance expectancy, effort expectancy, behavioural intention, enjoyment, innovativeness, social influence, brand loyalty and trust. The framework is part of Unified Theory on Acceptance and Use of Technology (UTAUT) (Venkatesh et al., 2003) which is the latest addition to the Technology Acceptance Model (TAM). This research will extend and change the UTAUT framework by adding brand loyalty as a potentially better measure of reward. 


\section{Hypothesis Development}

Behavioural intention describes an individual's subjective probability of accepting new technologies. Their shopping habits will change inside supermarkets/hypermarkets if they accept new shopping methods with an AR app. This variable has been introduced in Fishbein et al., (1975) research but has been fully incorporated into the Unified Theory on Acceptance and Use of Technology model by Venkatesh et al. (2003). Therefore, this research will examine the respondents' subjective probability of accepting AR apps for shopping in supermarkets/hypermarkets.

In its core form, the Unified Theory on Acceptance and Use of Technology model investigates the impact of performance expectancy, effort expectancy, social influence on behavioural intention, and facilitating conditions on user behaviour. Since AR apps are in their early usage phase, where only a tiny fraction of people use them, we discard the variables measuring facilitating conditions and actual use. Besides, the Unified Theory on Acceptance and Use of Technology model is often extended with various additional factors, ranging from brand loyalty to innovativeness. We investigate two sets of hypotheses: (i) hypothesis from the core Unified Theory on Acceptance and Use of Technology model and (ii) hypothesis from the extended Unified Theory on Acceptance and Use of Technology model. Besides, we investigate the impact of two control variables in the model: gender and education.

\section{Core UTAUT Model}

Performance expectancy defines how using a system will benefit the individual in performing specific activities (Venkatesh et al., 2003). This variable has been implemented in various researches in the retail sector and has confirmed a positive relationship with the behavioural intention variable (Giovannis et al., 2019). It is expected that the respondents of this research will use Augmented Reality apps in supermarkets/hypermarkets if they find them suitable. Based on these findings, we develop the following hypothesis:

H1: Performance expectancy is related to behavioural intention.

Effort expectancy is a core variable in establishing a technology acceptance by the respondents is the ease of using the system (Venkatesh et al., 2003). For the users to accept new technology, the interface and the process from the input to the output are crucial. Ease of use is needed for the Augmented Reality app to be accepted as other technologies were. That is the basis for the development of the second hypothesis:

H2: Effort expectancy is related to behavioural intention.

Peers, family members, and friends' opinions impact the individuals' perception of using a particular technology. The individual might be the technology pioneer in their group of friends. By pioneer's acceptance of new technology, their group of contacts might start to use it or not based on their review. The more positive social influence and support the individual is, the more accepting the new technology is (Kijsanayotin et al., 2009). Based on these presumptions, we develop the third hypothesis:

H3: Social influence is related to behavioural intention.

\section{Extended UTAUT Model}

According to Ramachandran et al. (2020), a loyal customer is committed to the product or company and is, therefore, less price-sensitive and less prone to experience other brands. If the companies would be interested in building an Augmented Reality app, they would certainly need to offer some 
reward to their customers. When done in a described way, brand loyalty should positively relate to behavioural intention, which is the foundation for the development of the fourth hypothesis:

H4: Brand loyalty is related to behavioural intention.

Enjoyment is needed in any technological aspect, as without it would be hard to reach global adoption scales. One of the best examples of global app awareness due to enjoyment is the "Pokemon Go" Augmented Reality app that also impacted the users' intention to use it (Ghazali et al., 2019). Mathwick et al. (2001) showed that Augmented Reality technology increases the shopping experience and the number of online purchases. Based on the above research, we developed the fifth hypothesis:

H5: Enjoyment is related to behavioural intention.

Being innovative in the majority of cases means being interested in more potential customers. This factor is essential in the ICT industry as it shows how interested an individual is in trying out a new technology (Agarwal et al., 1998). On the other hand, the acceptance of the innovation depends on the individual and can vary. The more a user is innovative, the higher the chances of understanding the benefits of using new technology such as Augmented Reality app in supermarkets/hypermarkets, which is the basis for the sixth hypothesis:

H6: Innovativeness is related to behavioural intention.

The trust is connected with the brand and the company, which means that if the customer knows the company for some time, it will develop a special relationship with it. It does not need to mean that it is only buying from one source and looking for loyalty programs, but choosing it over others in certain situations. Trust is essential in developing an intention towards using a new app developed by a particular company (Ramachandran et al., 2020). Based on these findings, we develop the following hypothesis:

H7: Trust is related to behavioural intention.

The research model has been developed (Figure 1), which shows the relations between the independent and the dependant variable. Core and Extended Unified Theory on Acceptance and Use of Technology independent variables are presented separately, while control variables represent the demographic research respondents data.

To test the above-stated hypothesis, survey research has been conducted. Empirical research has followed, which is described in the next chapter, Methodology.

\section{METHODOLOGY}

\section{Research Instrument}

Table 3 lists the variables relevant to the expanded Unified Theory on Acceptance and Use of Technology model, comprising 29 questions representing nine factors. A five-point Likert scale was used in the questionnaire for each of these questions, as accepted in similar research. The questionnaire has been constructed upon literature review (Saprikis et al., 2020, Venkatesh et al., 2003), while the Brand Loyalty variable has been added as an extension of the previous research questionnaires.

This article aimed to research the factors affecting potential customer behavioural intention of accepting new technologies such as Augmented Reality among the University of Zagreb student 


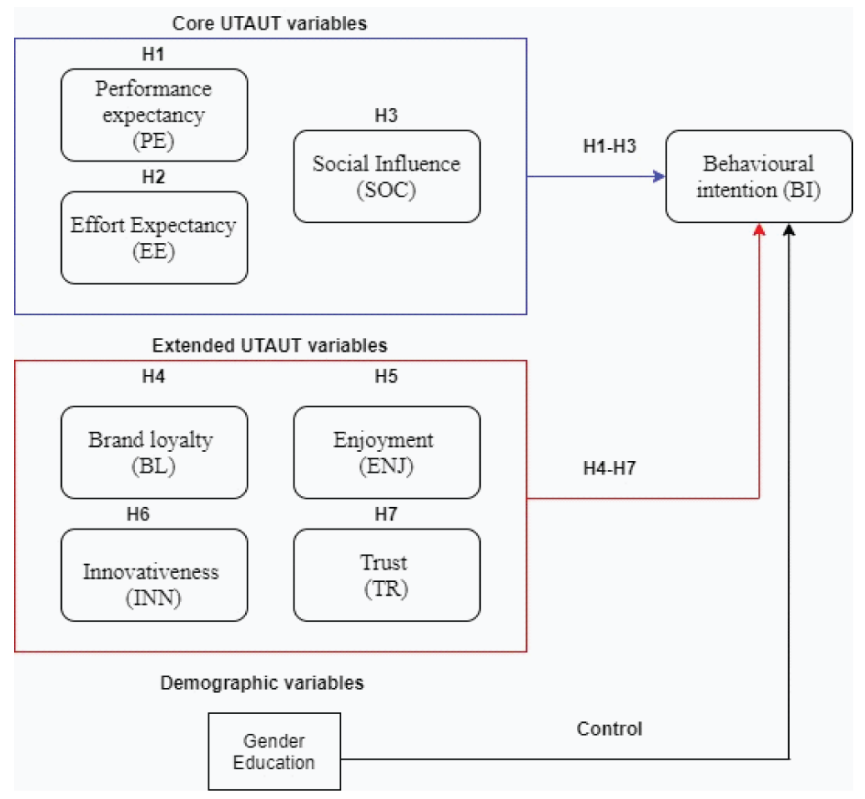

population. The target group has been younger population predominantly as it accepts new technologies faster; thus, determining the factors affecting their opinion on the Augmented Reality app usage in supermarkets/hypermarkets will be a great asset to the general population of Croatia, as supermarkets/ hypermarkets are visited by all surveyed participants at least once a week.

The questionnaire was compiled in the Croatian language due to the research respondents' base, and it was conveyed online between June and July 2021. The first part consisted of demographic questions. The central part of the research was consistent with respondents' opinions on the factors affecting behavioural intention of using Augmented Reality apps in supermarket/hypermarkets, as shown in this research results. The list of students was obtained through official University of Zagreb database and Social Media platforms such as Facebook student group pages. The online questionnaire itself has been conducted through Google forms, and students were invited via e-mail.

A total of 452 University of Zagreb students have been invited to participate. From the 452 student responses, 65 were accepted (15\% response rate) for the empirical analysis to research their attitudes towards using Augmented Reality apps in supermarkets/hypermarkets. Several male participants showed 26 (40\%), while females counted for 39 (60\%) out of 65 total respondents. The majority of the participants were Undergraduate students, $49(75 \%)$, while the rest were Graduate students, $16(25 \%)$. Due to the reason, that the study used a non-random sample, the results should be considered preliminary. 
Table 3. Operational definition of research variables

\begin{tabular}{|c|c|c|}
\hline Research variables & Operational Definition & Sources \\
\hline \multicolumn{3}{|c|}{ Core UTAUT variables } \\
\hline \multirow[t]{3}{*}{$\begin{array}{l}\text { Performance expectancy } \\
\text { (PE) }\end{array}$} & $\begin{array}{l}\text { PE1: I think that using an Augmented Reality app in a supermarket/hypermarket would help me } \\
\text { accomplish tasks more quickly }\end{array}$ & \multirow[t]{13}{*}{$\begin{array}{l}\text { Adapted from } \\
\text { Venkatesh et al., (2003) }\end{array}$} \\
\hline & $\begin{array}{l}\text { PE2: I think that using an Augmented Reality app in a supermarket/hypermarket would increase my } \\
\text { chances of achieving what is important to me }\end{array}$ & \\
\hline & PE3: I suppose an Augmented Reality app in a supermarket/hypermarket is useful & \\
\hline \multirow[t]{3}{*}{ Effort Expectancy (EE) } & $\begin{array}{l}\text { EE1: I think that learning how to use an Augmented Reality app in a supermarket/hypermarket would } \\
\text { be easy for me }\end{array}$ & \\
\hline & $\begin{array}{l}\text { EE2: I think that it would be easy for me to be able to use an Augmented Reality app in a } \\
\text { supermarket/hypermarket }\end{array}$ & \\
\hline & EE3: I think that I would find an Augmented Reality app in a supermarket/hypermarket easy to use & \\
\hline \multirow[t]{3}{*}{ Social Influence (SOC) } & $\begin{array}{l}\text { SOC1: People who are important to me think that I should use an Augmented Reality app in a } \\
\text { supermarket/hypermarket }\end{array}$ & \\
\hline & $\begin{array}{l}\text { SOC2: People who influence my behaviour think that I should use an Augmented Reality app in a } \\
\text { supermarket/hypermarket }\end{array}$ & \\
\hline & $\begin{array}{l}\text { SOC3: People whose opinions I value prefer that I should use an Augmented Reality app in a } \\
\text { supermarket/hypermarket }\end{array}$ & \\
\hline \multirow[t]{4}{*}{ Behavioural intention (BI) } & BI1: Given the chance. I am going to use an Augmented Reality app in a supermarket/hypermarket & \\
\hline & BI2: I intend to use an Augmented Reality app in a supermarket/hypermarket & \\
\hline & BI3: I expect I will use an Augmented Reality app in a supermarket/hypermarket in the future & \\
\hline & BI4: I will use an Augmented Reality app if available in a supermarket/hypermarket & \\
\hline \multicolumn{3}{|l|}{ Extended UTAUT variables } \\
\hline \multirow[t]{3}{*}{ Brand loyalty (BL) } & $\begin{array}{l}\text { BL1: I would use the Augmented Reality app inside the supermarket/hypermarket if it had discount } \\
\text { offers }\end{array}$ & \multirow[t]{3}{*}{ Author's work } \\
\hline & BL2: If the Augmented Reality app showed offers. I would use it inside a supermarket/hypermarket & \\
\hline & $\begin{array}{l}\text { BL3: If the Augmented Reality app gave me the possibility of loyalty and points collections. I would } \\
\text { use it inside a supermarket/hypermarket }\end{array}$ & \\
\hline \multirow[t]{3}{*}{ Enjoyment (ENJ) } & ENJ1: I think using an Augmented Reality app in a supermarket/hypermarket would be fun & \multirow{3}{*}{$\begin{array}{l}\text { Adapted from } \\
\text { Venkatesh et al., (2003) }\end{array}$} \\
\hline & $\begin{array}{l}\text { ENJ2: I think using an Augmented Reality app in a supermarket/hypermarket would be a pleasure } \\
\text { process }\end{array}$ & \\
\hline & ENJ3: I think using an Augmented Reality app in a supermarket/hypermarket would be enjoyable & \\
\hline \multirow{4}{*}{$\begin{array}{l}\text { Innovativeness } \\
\text { (INN) }\end{array}$} & INN1: I like using new technologies & \multirow{7}{*}{$\begin{array}{l}\text { Adapted from Saprikis } \\
\text { et al. }(2020)\end{array}$} \\
\hline & INN2: I like learning about new technologies & \\
\hline & $\begin{array}{l}\text { INN3: When I am informed about a new technological product. I try to find the opportunity to } \\
\text { experiment with it }\end{array}$ & \\
\hline & INN4: Compared to my friends and family. I am usually among the first to try new technologies & \\
\hline \multirow[t]{3}{*}{ Trust (TR) } & TR1: I think that I would trust Augmented Reality apps in a supermarket/hypermarket & \\
\hline & TR2: I think that a supermarket/hypermarket Augmented Reality app would be trustworthy & \\
\hline & $\begin{array}{l}\text { TR3: I think that I would strictly follow the terms of use while using an Augmented Reality app in a } \\
\text { supermarket/hypermarket }\end{array}$ & \\
\hline \multicolumn{3}{|l|}{ Control variables } \\
\hline Gender & 0-Female; 1-Male & \multirow{2}{*}{$\begin{array}{l}\text { Adapted from } \\
\text { Venkatesh et al. (2003) }\end{array}$} \\
\hline Education & 0-Undergraduate study; 1-Graduate study & \\
\hline
\end{tabular}

Source: Author's work 
Table 4. Frequency of augmented reality apps usage

\begin{tabular}{|l|l|l|l|}
\hline \multicolumn{1}{|c|}{ Period of augmented reality apps usage } & \multicolumn{1}{c|}{ Frequency } & \multicolumn{1}{c|}{ Cumulative \% } \\
\hline $1-2$ years & 2 & 3.1 & 3.1 \\
\hline $3-5$ years & 1 & 1.5 & 4.6 \\
\hline Less than one year & 14 & 21.5 & 26.2 \\
\hline No experience & 48 & 73.8 & 100 \\
\hline Total & 65 & 100 & \\
\hline
\end{tabular}

Source: Author's work

The majority of the respondents never had an experience with the Augmented Reality app, $73.8 \%$ of them. The minority of respondents had some experience but mainly less than one year, $21.5 \%$, while the rest was distributed among 1-2 years of experience, $3.1 \%$ and 3-5 years of experience, $1.5 \%$. Table 4 above provides a more detailed Augmented Reality app usage among the respondents from the sample.

\section{Statistical Analysis}

The questionnaire has been built on the prior research literature by adding the brand loyalty factor and the extended UTAT model variables. For this research, Structural Equation Modeling (SEM) is used as it combines both factor and multivariate regression analysis. Due to the nature of the research hypothesis design, it is recommended to use this statistical analysis technique (Hair 2013).

Research validity was checked, ensuring the content and study soundness. For that purpose, confirmatory factor analysis (CFA) was conducted. The confirmatory factor analysis checks the latent variables uniqueness and their ability to differentiate by testing for discriminate validity (Hu et al., 1999). Therefore, three recommended standards for model assessment were used: factor loading values should be higher than 0.4 , average variance extracted (AVE) should be higher than 0.5 , and composite reliability should exceed 0.6 (Hair 2013).

On the other hand, using correlation statistics (descriptive and non-parametric), possible soundness issues of low or negative correlations in the data have been researched. Furthermore, to check for the reliability of data, Cronbach's alpha was used.

The goodness of fit model and its indices, Chi-square index, Non-normed fit index (NNFI), Comparative fit index (CFI), and Root mean square error (RMSE) have been used. They are the starting point for the structural equations model (SEM) fit (Hooper et al., 2008, Hu et al., 1999). The SEM maximum likelihood estimation was used to statistically show the variable relations in the model, with a particular emphasis on the research hypothesis. Even though structural equation modelling can't establish strong links between intervention and outcome, it will examine the fit of the research model dataset. The parameter relation significance and the independent constructs internal amount of variance was tested to justify the research data fit.

Figure 2 shows the SEM development using JASP's software R-code method.

The research findings are shown in the Findings section below. 
Figure 2. R-code for the research model (Source: Authors' work)

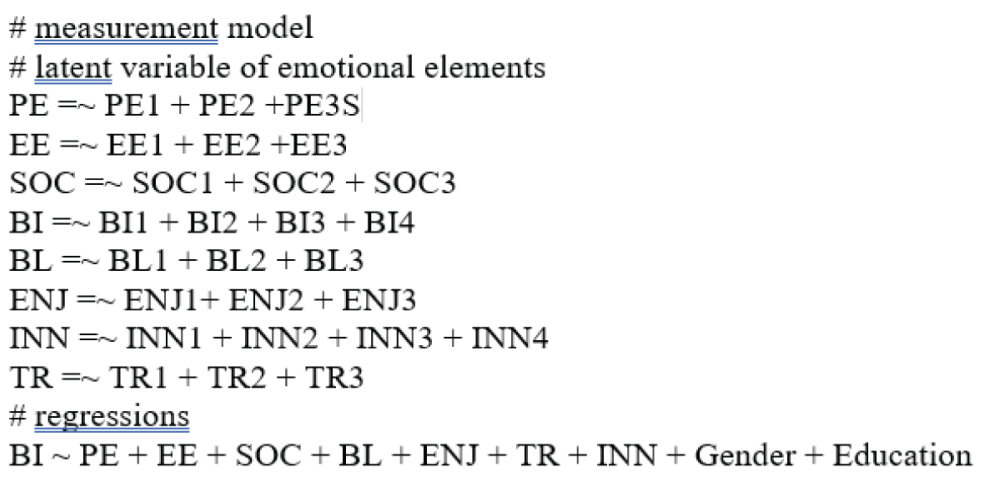

\section{FINDINGS}

\section{Validity Analysis}

The $t$ values with their loadings are shown in Table 5, provided by the confirmatory factor analysis, where discriminant validity was assessed. All $\lambda$ 's are higher than 0.50 . while $t$ values exceed the 1.96 thresholds, indicating data significance (Costello et al., 2005). Furthermore, Cronbach's alpha reliability analysis coefficients are higher than the 0.50 cut off value, indicating internal data consistency. Complementing previous findings, the average variance and composite reliability of the research variables are exceeding corresponding thresholds.

All variables in the model indicate a significance under $1 \%$ alpha level. Variable SOC is the only one that slightly shows lower estimates from the group, which could explain a potential differentiation between the respondents' answers due to various external factors impacting an individual accepting new technologies, such as the Augmented Reality.

\section{Descriptive Analysis}

Descriptive statistics of the model variables are shown in Table 6 below. Coefficients of variation show values between $34 \%$ (lowest point) and 69\% (highest point). This result indicates that the higher the coefficient of variation, the higher the level of dispersion around the mean (Kline 2004).

To test the normality of the distribution, the Kolmogorov Smirnov Z test was used. The Kolmogorov Smirnov $\mathrm{Z}$ test shows if the sample data is taken from the population following a hypothesized distribution. This research results show a Kolmogorov Smirnov Z test higher than 1.0 and significance is under 5\% alpha level. These results indicate a significant deviation in the data, and therefore research rejects the null hypothesis that the data is normally distributed.

Variable correlation might show that the research does not have enough diverse data to conclude significant and trustworthy findings. Spearman's non - parametric correlation analysis has been used, which shows the direction and the strength between the manifest variables. The results show that the values are primarily above 0.5 but not above 0.9 thresholds, except for the items in the same factor group, such as BI. Therefore, the data has a moderate to the high correlation between the variables. Tables 7 and 8 present the results of the correlation analysis.

In the next step, the model fit assessment is conducted. 
Table 5. Standardized loading estimates and t values - Cronbach's alpha

\begin{tabular}{|c|c|c|c|c|c|c|c|}
\hline Factor & Indicator & Symbol & Estimate & t value & p-value & R Squared & Cronbach's alpha \\
\hline \multirow[t]{3}{*}{ PE } & PE1 & $\lambda 11$ & 1.078 & 8.683 & $<.001$ & 0.749 & 0.915 \\
\hline & PE2 & $\lambda 12$ & 1.181 & 8.900 & $<.001$ & 0.772 & \\
\hline & PE3 & $\lambda 13$ & 1.210 & 9.513 & $<.001$ & 0.835 & \\
\hline \multirow[t]{3}{*}{$\mathrm{EE}$} & EE1 & $\lambda 21$ & 1.413 & 10.553 & $<.001$ & 0.928 & 0.916 \\
\hline & EE2 & $\lambda 22$ & 1.439 & 10.874 & $<.001$ & 0.958 & \\
\hline & EE3 & $\lambda 23$ & 1.208 & 9.297 & $<.001$ & 0.803 & \\
\hline \multirow[t]{3}{*}{ SOC } & SOC1 & $\lambda 31$ & 0.892 & 8.595 & $<.001$ & 0.760 & 0.899 \\
\hline & SOC2 & $\lambda 32$ & 0.938 & 8.609 & $<.001$ & 0.762 & \\
\hline & SOC3 & $\lambda 33$ & 0.959 & 8.329 & $<.001$ & 0.730 & \\
\hline \multirow[t]{4}{*}{ BI } & BI1 & $\lambda 41$ & 1.475 & 10.861 & $<.001$ & 0.952 & 0.986 \\
\hline & $\mathrm{BI} 2$ & $\lambda 42$ & 1.468 & 11.278 & $<.001$ & 0.989 & \\
\hline & $\mathrm{BI} 3$ & $\lambda 43$ & 1.378 & 10.833 & $<.001$ & 0.949 & \\
\hline & $\mathrm{BI} 4$ & $\lambda 44$ & 1.346 & 10.325 & $<.001$ & 0.902 & \\
\hline \multirow[t]{3}{*}{ BL } & BL1 & $\lambda 51$ & 1.427 & 10.493 & $<.001$ & 0.920 & 0.953 \\
\hline & BL2 & $\lambda 52$ & 1.479 & 11.065 & $<.001$ & 0.973 & \\
\hline & BL3 & $\lambda 53$ & 1.342 & 8.906 & $<.001$ & 0.762 & \\
\hline \multirow[t]{3}{*}{ ENJ } & ENJ1 & $\lambda 61$ & 1.508 & 10.024 & $<.001$ & 0.875 & 0.959 \\
\hline & ENJ2 & $\lambda 62$ & 1.392 & 10.311 & $<.001$ & 0.903 & \\
\hline & ENJ3 & $\lambda 63$ & 1.395 & 10.068 & $<.001$ & 0.879 & \\
\hline \multirow[t]{4}{*}{ INN } & INN1 & $\lambda 71$ & 1.482 & 10.690 & $<.001$ & 0.939 & 0.954 \\
\hline & INN2 & $\lambda 72$ & 1.494 & 10.943 & $<.001$ & 0.962 & \\
\hline & INN3 & $\lambda 73$ & 1.196 & 8.660 & $<.001$ & 0.736 & \\
\hline & INN4 & $\lambda 74$ & 1.160 & 8.325 & $<.001$ & 0.700 & \\
\hline \multirow[t]{3}{*}{ TR } & TR1 & $\lambda 81$ & 1.293 & 10.365 & $<.001$ & 0.911 & 0.934 \\
\hline & TR2 & $\lambda 82$ & 1.336 & 10.387 & $<.001$ & 0.913 & \\
\hline & TR3 & $\lambda 83$ & 1.140 & 8.113 & $<.001$ & 0.680 & \\
\hline
\end{tabular}

Source: Author's work

\section{Model Fit Assessment}

The JASP's statistical software programme R code method with "lavaan model" used for data analysis was implemented to develop the SEM equation to follow the research model. Table 9 represents the research goodness of fit with a chi-square of 653.139, 321 degrees of freedom, failing to reject the null hypothesis that the variables in the model are associated. All other indices show good model validity and fit. On the other hand, only Standardized Root Mean Square Residual (SMRM) indicated a slightly higher estimate of 0.001 above the benchmark level.

Following the results mentioned earlier, research data is a good fit for SEM analysis. Showing the directions and strength of the relations between the variables in the model will be presented, complementing the hypothesis testing in the Research model testing part below. 
Table 6. Descriptive analysis

\begin{tabular}{|c|c|c|c|c|c|c|}
\hline Indicator & $\mathbf{N}$ & Mean & Std. Dev. & Var. Coeff. & Kolmogorov Smirnov Z & Asymp. Sig. (2-tailed) \\
\hline PE1 & 65 & 2.65 & 1.26 & $47 \%$ & 1.771 & $0.004 * *$ \\
\hline PE2 & 65 & 2.71 & 1.35 & $50 \%$ & 1.421 & $0.035^{*}$ \\
\hline PE3 & 65 & 2.57 & 1.33 & $52 \%$ & 1.642 & $0.009 * *$ \\
\hline EE1 & 65 & 2.31 & 1.48 & $64 \%$ & 1.956 & $0.001 * *$ \\
\hline EE2 & 65 & 2.34 & 1.48 & $63 \%$ & 1.996 & $0.001 * *$ \\
\hline EE3 & 65 & 2.45 & 1.36 & $56 \%$ & 1.572 & $0.014 *$ \\
\hline SOC1 & 65 & 3.03 & 1.03 & $34 \%$ & 2.515 & $0.000 * *$ \\
\hline SOC2 & 65 & 3.22 & 1.08 & $34 \%$ & 2.310 & $0.000 * *$ \\
\hline SOC3 & 65 & 3.03 & 1.13 & $37 \%$ & 2.010 & $0.001 * *$ \\
\hline BI1 & 65 & 2.74 & 1.52 & $56 \%$ & 1.438 & $0.032 *$ \\
\hline $\mathrm{BI} 2$ & 65 & 2.77 & 1.49 & $54 \%$ & 1.530 & $0.018^{*}$ \\
\hline $\mathrm{BI} 3$ & 65 & 2.75 & 1.43 & $52 \%$ & 1.811 & $0.003 * *$ \\
\hline BI4 & 65 & 2.74 & 1.43 & $52 \%$ & 1.530 & $0.019^{*}$ \\
\hline BL1 & 65 & 2.43 & 1.50 & $62 \%$ & 1.730 & $0.005^{* *}$ \\
\hline BL2 & 65 & 2.48 & 1.51 & $61 \%$ & 1.680 & $0.007 * *$ \\
\hline BL3 & 65 & 2.60 & 1.55 & $60 \%$ & 1.637 & $0.009 * *$ \\
\hline ENJ1 & 65 & 2.65 & 1.62 & $61 \%$ & 1.848 & $0.002 * *$ \\
\hline ENJ2 & 65 & 2.60 & 1.48 & $57 \%$ & 1.706 & $0.006^{* *}$ \\
\hline ENJ3 & 65 & 2.57 & 1.50 & $58 \%$ & 1.626 & $0.010^{*}$ \\
\hline INN1 & 65 & 2.25 & 1.54 & $69 \%$ & 2.529 & $0.000 * *$ \\
\hline INN2 & 65 & 2.35 & 1.54 & $65 \%$ & 2.074 & $0.000^{* *}$ \\
\hline INN3 & 65 & 2.89 & 1.40 & $49 \%$ & 1.356 & 0.051 \\
\hline INN4 & 65 & 2.72 & 1.40 & $51 \%$ & 1.655 & $0.008 * *$ \\
\hline TR1 & 65 & 2.62 & 1.37 & $52 \%$ & 1.588 & $0.013^{*}$ \\
\hline TR2 & 65 & 2.63 & 1.41 & $54 \%$ & 1.827 & $0.003 * *$ \\
\hline TR3 & 65 & 2.68 & 1.39 & $52 \%$ & 1.441 & $0.031 *$ \\
\hline
\end{tabular}

Source: Authors' work

\section{Research Model Testing}

After testing various statistical methods, we can conclude that the overall model is a good fit. Using SEM for hypothesis testing, their significance levels ( $t$ value), the total amount of variation explained between the variables and the model itself (measured by the squared multiple correlation coefficient $-R^{2}$ ) is shown in Table 10. Furthermore, path coefficients of the hypothesis are shown as well under $5 \%$ significance level.

Research findings showed that the data t values, Cronbach's alpha, average variance and composite reliability exceed their thresholds, indicating internal data consistency and reliability. The collinearity test showed that the data is between medium to high correlation areas, while the sample distribution test indicated a non-normal distribution. The overall goodness of fit showed that the model is accepted for the following SEM analysis, complementing previous research results except for the non-normal data distribution. The non-normal sample distribution might be the case due to 
Table 7. Correlation analysis

\begin{tabular}{|l|l|l|l|l|l|l|l|l|l|l|l|l|c|}
\hline \multicolumn{1}{|c|}{ Variable } & PE1 & PE2 & PE3 & EE1 & EE2 & EE3 & SOC1 & SOC2 & SOC3 & BI1 & BI2 & BI3 & BI4 \\
\hline PE1 & 1 & $0.731^{*}$ & $0.745^{*}$ & $0.517^{*}$ & $0.558^{*}$ & $0.557^{*}$ & $0.403^{*}$ & $0.347^{*}$ & $0.421^{*}$ & $0.728^{*}$ & $0.754^{*}$ & $0.783^{*}$ & $0.768^{*}$ \\
\hline PE2 & & 1 & $0.782^{*}$ & $0.581^{*}$ & $0.510^{*}$ & $0.513^{*}$ & $0.426^{*}$ & $0.386^{*}$ & $0.440^{*}$ & $0.718^{*}$ & $0.747^{*}$ & $0.742^{*}$ & $0.717^{*}$ \\
\hline PE3 & & & 1 & $0.598^{*}$ & $0.612^{*}$ & $0.569^{*}$ & $0.424^{*}$ & $0.361^{*}$ & $0.496^{*}$ & $0.689^{*}$ & $0.704^{*}$ & $0.715^{*}$ & $0.723^{*}$ \\
\hline EE1 & & & & 1 & $0.887^{*}$ & $0.781^{*}$ & 0.171 & 0.205 & $0.367^{*}$ & $0.556^{*}$ & $0.562^{*}$ & $0.541^{*}$ & $0.515^{*}$ \\
\hline EE2 & & & & & 1 & $0.820^{*}$ & 0.097 & 0.109 & $0.311^{*}$ & $0.608^{*}$ & $0.585^{*}$ & $0.583^{*}$ & $0.521^{*}$ \\
\hline EE3 & & & & & & 1 & 0.164 & 0.192 & $0.321^{*}$ & $0.621^{*}$ & $0.591^{*}$ & $0.628^{*}$ & $0.612^{*}$ \\
\hline SOC1 & & & & & & & 1 & $0.750^{*}$ & $0.719^{*}$ & $0.447^{*}$ & $0.483^{*}$ & $0.470^{*}$ & $0.511^{*}$ \\
\hline SOC2 & & & & & & & & 1 & $0.718^{*}$ & $0.481^{*}$ & $0.522^{*}$ & $0.543^{*}$ & $0.535^{*}$ \\
\hline SOC3 & & & & & & & & & 1 & $0.601^{*}$ & $0.644^{*}$ & $0.578^{*}$ & $0.621^{*}$ \\
\hline BI1 & & & & & & & & & & 1 & $0.964^{*}$ & $0.932^{*}$ & $0.887^{*}$ \\
\hline BI2 & & & & & & & & & & & 1 & $0.956^{*}$ & $0.929^{*}$ \\
\hline BI3 & & & & & & & & & & & & 1 & $0.942^{*}$ \\
\hline BI4 & & & & & & & & & & & & & 1 \\
\hline
\end{tabular}

the low number of survey respondents, and thus large data deviation with a bigger sample size would be disregarded (Hair 2013).

The research results have shown that three out of seven hypotheses were accepted under a 5\% significance level. Enjoyment and Performance Expectancy showed positive and strong relationships while Effort Expectancy showed negative relation with behavioural intention. The model summary showed a high coefficient of determination and adjusted determination for the behavioural intention (dependent variable), meaning that $95 \%$ of the total variation for the dependent variable has been explained in this model.

Acceptance of hypothesis H1 is aligned with the Saprikis et al. (2020) research. This result is crucial in explaining the users' intention to accept Augmented Reality apps. It defines the users' benefit of using new technology, in their case, mobile Augmented Reality app for usage in shopping malls. Furthermore, as mentioned earlier, H1 is aligned with Shang et al. (2017), who proved the impact of performance expectancy on adopting a mobile Augmented Reality app for historical monuments. Lastly, Paulo et al. (2018) proved that performance expectancy impacts Augmented Reality app adoption's behavioural adoption intention variable in the tourism industry.

Effort Expectancy hypothesis H2 was accepted, aligned with Zuiderwijk et al.'s (2015) research. Furthermore, the Effort Expectancy variable showed a negative but significant relationship with the dependent variable. The lower the effort expectancy is to use the Augmented Reality app, the higher the intention of using the app. The majority of other articles find a positive relationship with the behavioural intention, meaning that they start with the fact that using new technology is not an easy process and therefore expect that higher efforts are needed in accepting and intention to use it (Chao, 2019, Sair et al., 2018). On the other hand, the less effort needed to use the app, the higher the probability of accepting it and the intention to use it increases, as this research shows.

As usually, consumers are fond of new shopping methods if they are attracted to them somehow. That way could be internal or external, social or financial, depending on the situation. Enjoyment hypothesis H5 defines the interface and overall joy of the Augmented Reality app usage among the potential users. The research found a strong positive and significant relation with behavioural intention aligned with other articles (Ghazali et al., 2019, Teo et al., 2011. Rizky et al., 2017). Therefore, H5 was accepted.

The social influence shows how important an individual's environment is in accepting new technologies and what role that individual is "playing". The role could be a pioneer who always 
Table 8. Correlation analysis (continued)

\begin{tabular}{|c|c|c|c|c|c|c|c|c|c|c|c|c|c|}
\hline Variable & BL1 & BL2 & BL3 & ENJ1 & ENJ2 & ENJ3 & INN1 & INN2 & INN3 & INN4 & TR1 & TR2 & TR3 \\
\hline PE1 & $0.767^{*}$ & $0.735^{*}$ & $0.723^{*}$ & $0.710^{*}$ & $0.771^{*}$ & $0.736^{*}$ & $0.651^{*}$ & $0.635^{*}$ & $0.580^{*}$ & $0.449^{*}$ & $0.651^{*}$ & $0.606^{*}$ & $0.675^{*}$ \\
\hline PE2 & $0.756^{*}$ & $0.735^{*}$ & $0.758^{*}$ & $0.658 *$ & $0.698 *$ & $0.646^{*}$ & $0.542^{*}$ & $0.500^{*}$ & $0.539 *$ & $0.456^{*}$ & $0.591^{*}$ & $0.607^{*}$ & $0.632 *$ \\
\hline PE3 & $0.779^{*}$ & $0.786^{*}$ & $0.736^{*}$ & $0.635^{*}$ & $0.735^{*}$ & $0.645^{*}$ & $0.641^{*}$ & $0.641^{*}$ & $0.538^{*}$ & $0.456^{*}$ & $0.628^{*}$ & $0.638^{*}$ & $0.761^{*}$ \\
\hline EE1 & $0.533^{*}$ & $0.547 *$ & $0.532 *$ & $0.534 *$ & $0.652 *$ & $0.645^{*}$ & $0.659^{*}$ & $0.595^{*}$ & $0.430^{*}$ & $0.463 *$ & $0.658^{*}$ & $0.679 *$ & $0.603^{*}$ \\
\hline EE2 & $0.561 *$ & $0.621^{*}$ & $0.580^{*}$ & $0.579 *$ & $0.687 *$ & $0.651 *$ & $0.710^{*}$ & $0.611^{*}$ & $0.490 *$ & $0.460 *$ & $0.621^{*}$ & $0.624^{*}$ & $0.612^{*}$ \\
\hline EE3 & $0.600^{*}$ & $0.594 *$ & $0.539^{*}$ & $0.571^{*}$ & $0.693^{*}$ & $0.651 *$ & $0.691^{*}$ & $0.621^{*}$ & $0.545^{*}$ & $0.466^{*}$ & $0.704 *$ & $0.630 *$ & $0.585^{*}$ \\
\hline SOC1 & $0.450^{*}$ & $0.387 *$ & $0.342^{*}$ & $0.421^{*}$ & $0.402 *$ & $0.433^{*}$ & $0.248^{*}$ & $0.348^{*}$ & $0.510^{*}$ & $0.449 *$ & $0.377 *$ & $0.344 *$ & $0.259^{*}$ \\
\hline SOC2 & $0.486^{*}$ & $0.425^{*}$ & $0.352 *$ & $0.440^{*}$ & $0.412^{*}$ & $0.491^{*}$ & $0.293 *$ & $0.350^{*}$ & $0.448^{*}$ & $0.519^{*}$ & $0.431^{*}$ & $0.388^{*}$ & $0.284^{*}$ \\
\hline SOC3 & $0.496^{*}$ & $0.517^{*}$ & $0.520 *$ & $0.615^{*}$ & $0.543^{*}$ & $0.642^{*}$ & $0.447^{*}$ & $0.457^{*}$ & $0.506^{*}$ & $0.543^{*}$ & $0.515^{*}$ & $0.576^{*}$ & $0.486^{*}$ \\
\hline BI1 & $0.805^{*}$ & $0.803^{*}$ & $0.799 *$ & $0.886^{*}$ & $0.878^{*}$ & $0.850^{*}$ & $0.665^{*}$ & $0.660^{*}$ & $0.753^{*}$ & $0.626^{*}$ & $0.753^{*}$ & $0.722 *$ & $0.699 *$ \\
\hline BI2 & $0.791 *$ & $0.788^{*}$ & $0.808^{*}$ & $0.910 *$ & $0.888^{*}$ & $0.878^{*}$ & $0.668^{*}$ & $0.666^{*}$ & $0.762 *$ & $0.654^{*}$ & $0.763^{*}$ & $0.738^{*}$ & $0.725^{*}$ \\
\hline BI3 & $0.838 *$ & $0.808^{*}$ & $0.778^{*}$ & $0.841^{*}$ & $0.890 *$ & $0.824^{*}$ & $0.653^{*}$ & $0.685^{*}$ & $0.732 *$ & $0.664^{*}$ & $0.770 *$ & $0.703 *$ & $0.688 *$ \\
\hline BI4 & $0.812 *$ & $0.773^{*}$ & $0.756^{*}$ & $0.815^{*}$ & $0.850^{*}$ & $0.820^{*}$ & $0.638 *$ & $0.652^{*}$ & $0.729 *$ & $0.654 *$ & $0.781^{*}$ & $0.703^{*}$ & $0.720^{*}$ \\
\hline BL1 & 1 & $0.941^{*}$ & $0.806^{*}$ & $0.769^{*}$ & $0.782 *$ & $0.732 *$ & $0.651^{*}$ & $0.643^{*}$ & $0.639 *$ & $0.570 *$ & $0.689 *$ & $0.661^{*}$ & $0.688^{*}$ \\
\hline BL2 & & 1 & $0.866^{*}$ & $0.825^{*}$ & $0.802 *$ & $0.790 *$ & $0.708^{*}$ & $0.668^{*}$ & $0.623^{*}$ & $0.549^{*}$ & $0.681^{*}$ & $0.717^{*}$ & $0.772^{*}$ \\
\hline BL3 & & & 1 & $0.860^{*}$ & $0.803^{*}$ & $0.729 *$ & $0.606^{*}$ & $0.572 *$ & $0.596^{*}$ & $0.548^{*}$ & $0.604 *$ & $0.675^{*}$ & $0.765^{*}$ \\
\hline ENJ1 & & & & 1 & $0.892^{*}$ & $0.894^{*}$ & $0.678^{*}$ & $0.654^{*}$ & $0.717^{*}$ & $0.582^{*}$ & $0.728 *$ & $0.769^{*}$ & $0.743^{*}$ \\
\hline ENJ2 & & & & & 1 & $0.863 *$ & $0.717^{*}$ & $0.731^{*}$ & $0.731 *$ & $0.610^{*}$ & $0.816^{*}$ & $0.777^{*}$ & $0.737^{*}$ \\
\hline ENJ3 & & & & & & 1 & $0.780 *$ & $0.715^{*}$ & $0.726^{*}$ & $0.600^{*}$ & $0.768^{*}$ & $0.779 *$ & $0.721^{*}$ \\
\hline INN1 & & & & & & & 1 & $0.892 *$ & $0.749^{*}$ & $0.721^{*}$ & $0.765^{*}$ & $0.781^{*}$ & $0.689^{*}$ \\
\hline INN2 & & & & & & & & 1 & $0.779^{*}$ & $0.789^{*}$ & $0.822 *$ & $0.785^{*}$ & $0.700^{*}$ \\
\hline INN3 & & & & & & & & & 1 & $0.786^{*}$ & $0.777^{*}$ & $0.709 *$ & $0.574^{*}$ \\
\hline INN4 & & & & & & & & & & 1 & $0.700^{*}$ & $0.659^{*}$ & $0.510 *$ \\
\hline TR1 & & & & & & & & & & & 1 & $0.886^{*}$ & $0.732 *$ \\
\hline TR2 & & & & & & & & & & & & 1 & $0.791 *$ \\
\hline
\end{tabular}

Source: Authors' workNote: * statistically significant at $1 \%$

Table 9. Research model fit

\begin{tabular}{|l|l|l|}
\hline \multicolumn{1}{|c|}{ Indicator } & \multicolumn{1}{c|}{ Model Estimated } & \multicolumn{1}{c|}{ Explanations } \\
\hline Chi-square $(\chi 2)$ & 653.139 & $\chi 2$ is not significant \\
\hline Degrees of freedom $(\mathrm{df})$ & 321 & \\
\hline $\mathrm{p}$ value & 0.000 & \\
\hline$\chi 2 / \mathrm{df}$ & 2.034 & Very good. close to 2 \\
\hline NNFI & 0.863 & Good fit $>0.8$ \\
\hline CFI & 0.884 & Good fit $>0.8$ \\
\hline SMRM & 0.061 & Good fit $<0.06$ \\
\hline
\end{tabular}

Source: Authors' work 
Table 10. Direct effects of path coefficients

\begin{tabular}{|c|c|c|c|c|c|}
\hline Hypothesis & Path Coeffcient & Std.error & Z Value & p Value & Conclusion \\
\hline \multicolumn{6}{|c|}{ Core UTAUT variables } \\
\hline $\mathrm{H} 1: \mathrm{PE} \rightarrow \mathrm{BI}$ & 0.461 & 0.206 & 2.244 & $0.025^{*}$ & $\mathrm{H} 1 \checkmark(5 \%)$ \\
\hline $\mathrm{H} 2: \mathrm{EE} \rightarrow \mathrm{BI}$ & -0.232 & 0.097 & -2.381 & $0.017^{*}$ & $\mathrm{H} 2 \boldsymbol{\checkmark}(5 \%)$ \\
\hline H3: SOC $\rightarrow$ BI & 0.087 & 0.112 & 0.778 & 0.436 & $\mathrm{H} 3 \varnothing$ \\
\hline \multicolumn{6}{|c|}{ Extended UTAUT variables } \\
\hline $\mathrm{H} 4: \mathrm{BL} \rightarrow \mathrm{BI}$ & -0.241 & 0.196 & -1.226 & 0.220 & $\mathrm{H} 4 \varnothing$ \\
\hline $\mathrm{H} 5: \mathrm{ENJ} \rightarrow \mathrm{BI}$ & 1.058 & 0.219 & 4.834 & $<.001^{* *}$ & $\mathrm{H} 5 \checkmark(5 \%)$ \\
\hline H6: INN $\rightarrow$ BI & -0.075 & 0.182 & -0.409 & 0.683 & $\mathrm{H} 6 \varnothing$ \\
\hline $\mathrm{H} 7: \mathrm{TR} \rightarrow \mathrm{BI}$ & 0.003 & 0.122 & 0.025 & 0.980 & $\mathrm{H} 7 \varnothing$ \\
\hline \multicolumn{6}{|l|}{ Control variables } \\
\hline Gender $\rightarrow$ BI & -0.017 & 0.121 & -0.143 & 0.886 & Control $1 \varnothing$ \\
\hline Education $\rightarrow$ BI & -0.104 & 0.121 & -0.858 & 0.391 & Control $2 \mathrm{H} 3 \varnothing$ \\
\hline R-square & \multicolumn{4}{|l|}{0.956} & Model is representative \\
\hline
\end{tabular}

Note: ** statistically significant at $1 \% ;{ }^{*} 5 \%$

Figure 3. Path Diagram with path coefficients estimates and their significance levels (Source: Authors' work)

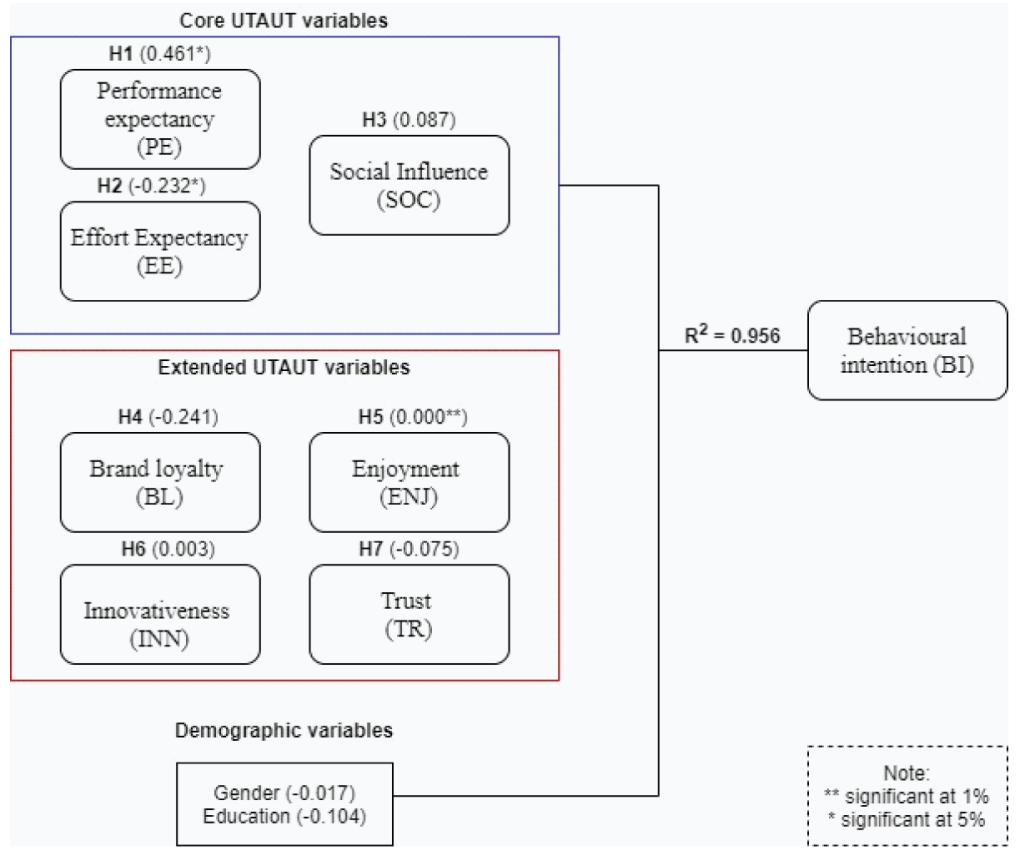


investigates new ways of achieving something or a person not interested in changing its habits. The hypothesis $\mathrm{H} 3$ was rejected by the research instead of the Unified Theory on Acceptance and Use of Technology model theory but is correlated with other research. Paulo et al. (2018) and Shang et al. (2017) showed that social influence does not directly affect behavioural intention.

Lastly, hypotheses H4, H6 and H7 are insignificant; thus, they were rejected from the model. There is a mix of results when previous researches are taken into consideration. Saprikis et al. (2020) rejected both Trust and Innovativeness, while Kim et al. (2020) showed that the more innovative a person is, the more positively correlated with the behavioural intention. Furthermore, Kim et al. (2020) stated that technological acceptance depends on the customers' subjective matters where trust and innovativeness step in. On the other hand, Brand Loyalty results proved the opposite of Ramachandran et al. (2020) that defined a positive relation with purchase intention, although stating that it depends on the level of loyalty in which customers might be. Therefore, depending on the sample size, demographic and geographic data, research results might vary for these variables.

\section{CONCLUSION}

In this paper, an overview of a general technological acceptance model was presented. Upon thorough literature review, an extended Unified Theory on Acceptance and Use of Technology model was constructed and validated. The research results demonstrated that only two variables out of seven showed robust, mostly positive and one negative statistically significant correlation. Components relation was measured using a University of Zagreb student sample with obtained results presented and analyzed. The first research question (RQ1) investigated the factors and behavioural parameters that motivate respondents' opinions on AR apps in super and hypermarkets. The results show that PE, ENJ and EE significantly influence an individual's behavioural intention to accept and use Augmented Reality. The strongest correlation with the dependent variable was captured by ENJ, which showed that the potential adoption of new technology needs to be entertaining for the end-user to accept it, providing the answer to the second research question (RQ2), investigating what factors stimulate individuals the most to adopt Augmented Reality apps?. Research hypotheses were developed to justify the research questions in the essential individual's aspects in accepting new technologies. Knowing each significant variable's strength and direction allows the research to point out its importance, as was the case with Enjoyment. According to this research results, with a combination of both research questions, further academic research and practital implications will have a foundation for further research or field implementation.

Results of this research confirm existing literature findings, indicating further key discussion points. Confirmatory factor analysis (CFA) was used to determine the direct relationship of the independent variables on the dependent. Mainly due to sample size limitations, the entire research hypotheses were not supported, and the normal sample distribution was not achieved. Additional nonsignificance can be seen in the change of the Unified Theory on Acceptance and Use of Technology model, which had a different array of variables. Three out of seven hypotheses were supported, from which PE corresponds with the Saprikis et al. (2020), ENJ with Teo et al. (2011) and Ghazali et al. (2019) and EE with Zuiderwijk et al. (2015). Performance Expectancy (H1) with a robust positive significance is the most critical finding of this research. It shows that potential users will look for certain benefits in supermarket/hypermarket shopping by using the app. The PE variable was rarely used in AR mobile environment, and its significance is therefore valuable.

Enjoyment's (H5) variable's vital positive significance confirms the other research results (Ghazali et al., 2019, Teo et al., 2011) of joy as an essential element in accepting new Augmented Reality technologies. Thirdly, Effort Expectancy (H2), one of the core variables of the Unified Theory on Acceptance and Use of Technology model, showed significant relation, contradictory to the Saprikis et al. (2020). The reason could be seen in the different context of research, where Saprikis et al. (2020) researched shopping malls environments, while this research-based it on a more specific 
and frequently used supermarkets/hypermarkets environment. According to the research results, the most crucial aspect when deciding on whether or not to use a new technological innovation such as the Augmented Reality is Enjoyment (ENJ), followed by potential benefits gained by using the app (PE) and effort expectancy (EE).

Both scholars and practitioners can use this research. Scholars may use it to develop their research on further and potentially widely spread Augmented Reality technology using the Unified Theory on Acceptance and Use of Technology model. Extending the Unified Theory on Acceptance and Use of Technology model and validating the existing one are possible in different industries and demographic groups. On the other hand, practitioners could find it helpful in understanding their potential customer base in launching a new technological project, benchmarking their performance by the research results or using them for future projections. The research results and frameworks could be used in different settings where new technology is developed. At the same time, there is a need of knowing the acceptance rate among the specific targeted population.

There are several limitations of this research. Sample limitations and respondent base need to be expanded to gain a higher proportion of variables significant correlations. The student population should be expanded by accepting respondents up to 30 years of age and potentially conducting crosscountry or cross-country research. The same framework could be used in various environments and is not limited to the supermarket/hypermarket business models. The possibility of a large and more diverse sample might show the normal data distribution and complement this research results even further. As previously mentioned, this paper reveals several possible further research directions. One of them is to use the existing framework across various industries while keeping the respondents' base the same. Another way could be to expand the research framework and implement it in different demographic or geographic locations. 


\section{REFERENCES}

Agarwal, R., \& Prasad, J. (1998). A Conceptual and Operational Definition of Personal Innovativeness in the Domain of Information Technology. Information Systems Research, 9(2), 204-215. doi:10.1287/isre.9.2.204

Ali, M. A., Hoque, M. R., \& Alam, K. (2018). An empirical investigation of the relationship between e-government development and the digital economy: The case of Asian countries. Journal of Knowledge Management, 22(5), 1176-1200. doi:10.1108/JKM-10-2017-0477

Alkhamisi, A. O., \& Monowar, M. M. (2013). Rise of Augmented Reality: Current and Future Application Areas. International Journal of Internet and Distributed Systems, 01(04), 25-34. doi:10.4236/ijids.2013.14005

Bach, P. M., Spremić. M., \& Suša Vugec. D. (2018). Integrating Digital Transformation Strategies into Firms: Values. Routes and Best Practice Examples. In Management and Technological Challenges in the Digital Age. CRC Press.

Bharadwaj, A., Sawy, O. A., Pavlou, P., \& Venkatraman, N. (2013). Digital business strategy: Toward a next generation of insights. Management Information Systems Quarterly, 37(2), 471-482. doi:10.25300/ MISQ/2013/37:2.3

Chao, C. M. (2019). Factors Determining the Behavioral Intention to Use Mobile Learning: An Application and Extension of the UTAUT Model. Frontiers in Psychology, 10, 1652. Advance online publication. doi:10.3389/ fpsyg.2019.01652 PMID:31379679

Chung, N., Han, H., \& Joun, Y. (2015). Tourists' intention to visit a destination: The role of augmented reality (AR) application for a heritage site. Computers in Human Behavior, 50, 588-599. doi:10.1016/j.chb.2015.02.068

Cimperman, M., Makovec Brenčič, M., \& Trkman, P. (2016). Analyzing older users' home telehealth services acceptance behavior-Applying an Extended UTAUT model. International Journal of Medical Informatics, 90, 22-31. doi:10.1016/j.ijmedinf.2016.03.002 PMID:27103194

Costello, A. B., \& Osborne, J. (2005). Best practices in exploratory factor analysis: Four recommendations for getting the most from your analysis. Practical Assessment, Research \& Evaluation, 10(1), 7.

Douglass, R. (1977). Article. Philosophy \& Rhetoric, 10(2), 130-132. Retrieved August 24, 2021, from http:// www.jstor.org/stable/40237022

Furjan, M. T., Tomičić-Pupek, K., \& Pihir, I. (2020). Understanding Digital Transformation Initiatives: Case Studies Analysis. Business Systems Research Journal, 11(1), 125-141. doi:10.2478/bsrj-2020-0009

Tomičić Furjan, M., Tomičić-Pupek, K., \& Pihir, I. (2020). Understanding Digital Transformation Initiatives: Case Studies Analysis. Business Systems Research: International journal of the Society for Advancing Innovation and Research in Economy, 11(1), 125-141. 10.2478/bsrj-2020-0009

Ghazali, E., Mutum, D. S., \& Woon, M. Y. (2019). Exploring player behavior and motivations to continue playing Pokémon GO. Information Technology \& People, 32(3), 646-667. doi:10.1108/ITP-07-2017-0216

Giovanis, A., Assimakopoulos, C., \& Sarmaniotis, C. (2019). Adoption of mobile self-service retail banking technologies. International Journal of Retail \& Distribution Management, 47(9), 894-914. doi:10.1108/ IJRDM-05-2018-0089

Hooper. D., Coughlan. J.P., \& Mullen. M.R. (2008). Structural equation modelling: guidelines for determining model fit. 10.21427/D7CF7R

Hu, L., \& Bentler, P. M. (1999). Cut-off criteria for fit indexes in covariance structure analysis: Conventional criteria versus new alternatives. Structural Equation Modeling, 6(1), 1-55. doi:10.1080/10705519909540118

Huang, T. L., \& Liao, S. (2014). A model of acceptance of augmented-reality interactive technology: The moderating role of cognitive innovativeness. Electronic Commerce Research, 15(2), 269-295. doi:10.1007/ s10660-014-9163-2

Karpischek, S., \& Michahelles, F. (2010). my2cents—Digitizing consumer opinions and comments about retail products. Proceedings of the Internet of Things (IoT). 
Keisidou, E., Sarigiannidis, L., \& Maditinos, D. (2011). Consumer characteristics and their effect on accepting online shopping. in the context of different product types. International Journal of Business, 6, 31-51.

Kijsanayotin, B., Pannarunothai, S., \& Speedie, S. M. (2009). Factors influencing health information technology adoption in Thailand's community health centers: Applying the UTAUT model. International Journal of Medical Informatics, 78(6), 404-416. doi:10.1016/j.ijmedinf.2008.12.005 PMID:19196548

Kim, J., \& Forsythe, S. (2008). Adoption of Virtual Try-on technology for online apparel shopping. Journal of Interactive Marketing, 22(2), 45-59. doi:10.1002/dir.20113

Kline, R. B. (2004). Principles and Practice of Structural Equation Modeling. Guilford Publications.

Korn, K. C., \& Pine, B. J. II. (2011). The Typology of Human Capability: A new guide to rethinking the potential for digital experience offerings. Strategy and Leadership, 39(4), 35-40. doi:10.1108/10878571111147396

Kounavis, C. D., Kasimati, A. E., \& Zamani, E. D. (2012). Enhancing the tourism experience through mobile augmented reality: Challenges and prospects. International Journal of Engineering Business Management, 4 , 10. doi: $10.5772 / 51644$

Kourouthanassis, P., Boletsis, C., Bardaki, C., \& Chasanidou, D. (2015). Tourists responses to mobile augmented reality travel guides: The role of emotions on adoption behavior. Pervasive and Mobile Computing, 18, 71-87. doi:10.1016/j.pmcj.2014.08.009

Lee, K. (2012). Augmented Reality in Education and Training. TechTrends, 56(2), 13-21. doi:10.1007/s11528012-0559-3

Liu, Y. C., Lu, S. J., Kao, C. Y., Chung, L., \& Tan, K. H. (2019). Comparison of AR and physical experiential learning environment in supporting product innovation. International Journal of Engineering Business Management, 11. Advance online publication. doi:10.1177/1847979019839578

Mabić, M., \& Gašpar, D. (2019). Do Higher Education Institutions Foster Critical Thinking? - Students' Perspective. Proceedings of the ENTRENOVA - ENTerprise REsearch InNOVAtion Conference, 5(1), $224-231$. Retrieved from https://hrcak.srce.hr/ojs/index.php/entrenova/article/view/13760

Martinčević, I., Črnjević, S., \& Klopotan, I. (2020). Fintech Revolution in the Financial Industry. Proceedings of the ENTRENOVA - ENTerprise REsearch InNOVAtion Conference, 6(1), 563-571. Retrieved from https:// hrcak.srce.hr/ojs/index.php/entrenova/article/view/13510-spominjeseARukontekstuFintech-a

Mathwick, C., Malhotra, N., \& Rigdon, E. (2001b). Experiential value: conceptualization. measurement and application in the catalog and Internet shopping environment. Journal of Retailing, 77(1), 39-56. 10.1016/ S0022-4359(00)00045-2

Merkaš, Z., Perkov, D., \& Bonin, V. (2020). The Significance of Blockchain Technology in Digital Transformation of Logistics and Transportation. International Journal of E-Services and Mobile Applications, 12(1), 1-20. doi:10.4018/IJESMA.2020010101

Mydyti, H., \& Kadriu, A. (2021). The Impact of Chatbots in Driving Digital Transformation. International Journal of E-Services and Mobile Applications, 13(4), 88-104. doi:10.4018/IJESMA.2021100106

Olsson, T., \& Salo, M. (2011). Online user survey on current mobile augmented reality applications. 2011 10th IEEE International Symposium on Mixed and Augmented Reality. doi:10.1109/ISMAR.2011.6092372

Opiła. J. (2019). Role of visualization in a knowledge transfer process. Business Systems Research: International Journal of the Society for Advancing Innovation and Research in Economy, 10(1), 164-179. 10.2478/bsrj-20190011

Paulo, M. M., Rita, P., Oliveira, T., \& Moro, S. (2018). Understanding mobile augmented reality adoption in a consumer context. Journal of Hospitality and Tourism Technology, 9(2), 142-157. doi:10.1108/JHTT-012017-0006

Hari, J. F., Jr. (2013). Multivariate Data Analysis. Pearson Education Limited.

Plewa, C., Troshani, I., Francis, A., \& Rampersad, G. (2012). Technology adoption and performance impact in innovation domains. Industrial Management \& Data Systems, 112(5), 748-765. doi:10.1108/02635571211232316 
Ramachandran, S., \& Balasubramanian, S. (2020). Examining the Moderating Role of Brand Loyalty among Consumers of Technology Products. Sustainability, 12(23), 9967. doi:10.3390/su12239967

Rese, A., Schreiber, S., \& Baier, D. (2014). Technology acceptance modeling of augmented reality at the point of sale: Can surveys be replaced by an analysis of online reviews? Journal of Retailing and Consumer Services, 21(5), 869-876. doi:10.1016/j.jretconser.2014.02.011

Sachs, G. (2016). Virtual and Augmented Reality: Understanding the race for next computing platform. The Golden Sachs Inc. https://www.goldmansachs.com/insights/pages/technology-driving-innovation-folder/virtualand-augmented-reality/report.pdf

Sair, S. A. (2018). EconStor: Effect of performance expectancy and effort expectancy on the mobile commerce adoption intention through personal innovativeness among Pakistani consumers. EconStor. https://www.econstor. eu/handle/10419/188355

Saprikis, V., Markos, A., Zarmpou, T., \& Vlachopoulou, M. (2018). Mobile Shopping Consumers' Behavior: An Exploratory Study and Review. Journal of Theoretical and Applied Electronic Commerce Research, 13(1), 71-90. doi:10.4067/S0718-18762018000100105

Septiani, R., Handayani, P. W., \& Azzahro, F. (2017b). Factors that Affecting Behavioral Intention in Online Transportation Service: Case study of GO-JEK. Procedia Computer Science, 124, 504-512. doi:10.1016/j. procs.2017.12.183

Shang, L. W., Siang, T. G., Zakaria, M. H. B., \& Emran, M. H. (2017). Mobile augmented reality applications for heritage preservation in UNESCO world heritage sites through adopting the UTAUT model. 10.1063/1.4980928

Šimičević, V., Jurić, V., \& Starešinić, B. (2020). Utilization of Forecasting Methods for Cryptocurrencies. Proceedings of the ENTRENOVA - ENTerprise REsearch InNOVAtion Conference, 6(1), 124-133. Retrieved from https://hrcak.srce.hr/ojs/index.php/entrenova/article/view/13444

Spremić. (2020). Fostering Innovation and Value Creation Through Ecosystems. Leadership, Management, and Adoption Techniques for Digital Service Innovation. doi:10.4018/978-1-7998-2799-3.ch002

Spremic, M. (2017). Governing Digital Technology - how Mature IT Governance can help in Digital Transformation? International Journal of Economics and Management Systems, 2, 214-223. https://www.bib. irb.hr/934731

Teo, T., \& Noyes, J. (2011). An assessment of the influence of perceived enjoyment and attitude on the intention to use technology among pre-service teachers: A structural equation modeling approach. Computers \& Education, 57(2), 1645-1653. doi:10.1016/j.compedu.2011.03.002

Topalović, A., \& Azzini, A. (2020). Data Mining Applications in SMEs: An Italian Perspective. Business Systems Research: International journal of the Society for Advancing Innovation and Research in Economy, 11(3), 127-146. 10.2478/bsrj-2020-0031

Tsioustas, C., Petratou, D., Kaliakatsos-Papakostas, M., Katsouros, V., Kastritsis, A., Christantonis, K., Diamantaras, K., \& Loupis, M. (2020). Innovative Applications of Natural Language Processing and Digital Media in Theatre and Performing Arts. Proceedings of the ENTRENOVA - ENTerprise REsearch InNOVAtion Conference, 6(1), 84-96. Retrieved from https://hrcak.srce.hr/ojs/index.php/entrenova/article/view/13436

van Boom, D. (2019, August 1). Pokemon Go has crossed 1 billion in downloads. CNET. https://www.cnet.com/ tech/mobile/pokemon-go-has-crossed-1-billion-in-downloads/

Venkatesh, M., Morris, , Davis, , \& Davis, . (2003). User Acceptance of Information Technology: Toward a Unified View. Management Information Systems Quarterly, 27(3), 425. doi:10.2307/30036540

Verhagen, T., van Nes, J., Feldberg, F., \& van Dolen, W. (2014). Virtual Customer Service Agents: Using Social Presence and Personalization to Shape Online Service Encounters. Journal of Computer-Mediated Communication, 19(3), 529-545. doi:10.1111/jcc4.12066

Weill, P., \& Ross, J. (2004). IT Governance: How Top Performers Manage IT Decision Rights for Superior Results (1st ed.). Harvard Business Review Press.

Wulf, T., \& Baldwin, M. (2020). Being a kid again: Playing Pokémon Go contributes to wellbeing through nostalgia. Studies in Communication and Media, 9(2), 241-263. doi:10.5771/2192-4007-2020-2-241 
Yi, M. Y., Fiedler, K. D., \& Park, J. S. (2006). Understanding the Role of Individual Innovativeness in the Acceptance of IT-Based Innovations: Comparative Analyses of Models and Measures. Decision Sciences, 37(3), 393-426. doi:10.1111/j.1540-5414.2006.00132.x

Yu, C. (2012). Factors Affecting Individuals to Adopt Mobile Banking: Empirical Evidence from the Utaut Model. Journal of Electronic Commerce Research, 13, 104-121.

Zhao, F., Wallis, J., \& Singh, M. (2015). E-government development and the digital economy: A reciprocal relationship. Internet Research, 25(5), 734-766. doi:10.1108/IntR-02-2014-0055

Zuiderwijk, A., Janssen, M., \& Dwivedi, Y. K. (2015). Acceptance and use predictors of open data technologies: Drawing upon the unified theory of acceptance and use of technology. Government Information Quarterly, 32(4), 429-440. doi:10.1016/j.giq.2015.09.005

Ivan Jajic is a Ph.D. student at the Faculty of Economics and Business (FEB), University of Zagreb, Croatia. He holds a B.Sc. in Business from the Faculty of Economics and Business (FEB), University of Zagreb, Croatia, and an M.Sc. in Business Administration specialization in Financial Management from the School of Business and Economics (SBE), Vrije Universiteit Amsterdam, The Netherlands. He has corporate experience in revenue management, controlling and product management. Furthermore, his main research interests are the digital economy, IT audit and financial markets.

Mario Spremić is a full professor at the Department of Informatics, Faculty of Economics and Business (FEB), University of Zagreb, Croatia, and a guest lecturer at several international institutions (such as Imperial College London). He holds a B.Sc. in mathematics, and M.Sc. in IT management and Ph.D. in business, all from the University of Zagreb. He joined FEB (Zagreb), in 2000, with previous corporate experience as a computer programmer and project manager. Mario has participated in executive education programs at MIT Sloan School of Management and EFMD Executive Academy. He has broad experience in international accreditation of higher education institutions (EQUIS, AACSB, EPAS peer-review). His main research interest areas are digital computing, the digital economy, ICT governance cyber security, and IT auditing.

Ivan Miloloža graduated from the Faculty of Economics in Zagreb. He lived and worked abroad in the period 1983rd to 1986th (Argentina and Netherland). Since 1986 he has been employed in the company Munja, the only Croatian battery producer, where he held almost all management functions and is currently Chairman of the Board (since 1999). He held many social functions in various government bodies, associations, and banks, and he was a participant and a guest lecturer at numerous national and international Conferences. He received his doctorate in 2015 at the Faculty of Economics in Osijek. Currently, he is an associate professor and Vide Dean at Faculty for Dental Medicine \& Health. 